\title{
Habitat associations of saproxylic beetles in the southeastern United States: A comparison of forest types, tree species and wood postures
}

\author{
Michael D. Ulyshen *, James L. Hanula \\ USDA Forest Service, 320 Green Street, Athens, GA 30602, United States
}

\section{A R T I C L E I N F O}

\section{Article history:}

Received 29 April 2008

Received in revised form 4 August 2008

Accepted 28 September 2008

\section{Keywords:}

Biodiversity

Coarse woody debris

Dead wood

Forest canopy

Resource partitioning

Vertical stratification

\begin{abstract}
A B S T R A C T
Saproxylic beetles are highly sensitive to forest management practices that reduce the abundance and variety of dead wood. However, this diverse fauna continues to receive little attention in the southeastern United States even though this region supports some of the most diverse, productive and intensively managed forests in North America. In this replicated three-way factorial experiment, we investigated the habitat associations of saproxylic beetles on the coastal plain of South Carolina. The factors of interest were forest type (upland pine-dominated vs. bottomland hardwood), tree species (Quercus nigra L., Pinus taeda L. and Liquidambar styraciflua L.) and wood posture (standing and downed dead wood, i.e., snags and logs). Wood samples were taken at four positions along each log and snag (lower bole, middle bole, upper bole and crown) $\sim 11$ months after the trees were killed and placed in rearing bags to collect emerging beetles. Overall, 33,457 specimens from 52 families and $\geq 250$ species emerged. Based on an analysis of covariance, with surface area and bark coverage as covariates, saproxylic beetle species richness differed significantly between forest types as well as between wood postures. There were no significant interactions. Species richness was significantly higher in the upland pine-dominated stand than the bottomland hardwood forest, possibly due to higher light exposure and temperature in upland forests. Although L. styraciflua yielded more beetle species (152) than either Q. nigra (122) or P. taeda (125), there were no significant differences in species richness among tree species. There were also no relationships evident between relative tree abundance and observed or expected beetle species richness. Significantly more beetle species emerged from logs than from snags. However snags had a distinct fauna including several potential canopy specialists. Our results suggest that conservation practices that retain or create entire snags as opposed to high stumps or logs alone will most greatly benefit saproxylic beetles in southeastern forests.
\end{abstract}

Published by Elsevier B.V.

\section{Introduction}

Although it is now widely recognized that saproxylic beetles are highly sensitive to long-term losses of dead wood, virtually nothing is known about the status of this diverse community in the intensively managed forests of the southeastern United States. However, this region faces a number of continuing (e.g., timber harvesting), intensifying (e.g., urbanization and habitat fragmentation), and emerging (e.g. biofuel production) threats to saproxylic organisms (Wear, 1996; Harding, 2007). The southeastern United States contains $40 \%$ of the country's timberland and $90 \%$ of the forests within the region are controlled by private landowners (Wear, 1996, and references therein). Around 22\% of the land held by private landowners is managed intensively

\footnotetext{
* Corresponding author.

E-mail address: mulyshen@hotmail.com (M.D. Ulyshen).
}

(typically on 30-50 yr rotations) for timber production by forest industries (Wear, 1996). The remainder is managed variously by a wide variety of landowners (Wear, 1996). Conserving saproxylic beetles and other organisms in this complex landscape will require great care and understanding. Unfortunately, too little is known about the basic life histories and habitat requirements of most species to prioritize actions or to make informed decisions. Here we investigate the habitat associations of saproxylic beetles on the upper coastal plain of the southeastern United States. The main factors of interest are summarized below.

1. Forest type. The coastal plain of the southeastern United States is dominated by pines on relatively dry upland sites and by mixed hardwoods on mesic bottomland sites. The relative importance of these two main forest types to saproxylic beetles remains unknown. Upland pine forests are more extensive than bottomland hardwood forests throughout the region. However, bottomland hardwood forests support more diverse tree species 
assemblages and may therefore be disproportionately important to the saproxylic beetle fauna. A number of factors likely to differ between forest types, such as canopy coverage (Økland, 2002), light exposure (Lindhe et al., 2005) and humidity (Warriner et al., 2004), may also have important consequences for the structure and species richness of saproxylic beetle communities. In this study we sampled saproxylic beetles in both an upland and bottomland forest. We predicted that overall beetle richness would be higher in the bottomland forest than in the upland forest due to the higher diversity of tree species in bottomland forests.

2. Tree species. We sampled wood from three tree species, each of which differed in abundance between upland and bottomland forests, to evaluate the effects of relative tree abundance on the diversity and composition of saproxylic beetles. This question has particularly important implications for saproxylic beetle conservation, but remains largely unstudied. We predicted a significant interaction between tree species and forest type due to differences in relative tree species abundances between the two forest types.

3. Wood posture. A large volume and variety of resources are available to saproxylic insects above the ground in the form of standing dead trees (i.e., snags), dead branches and twigs, and rotting heart wood (Fonte and Schowalter, 2004). For example, in a temperate broadleaved forest in Sweden, Nordén et al. (2004) found snags made up about $22 \%$ of total dead wood volume and another $6 \%$ was attributed to dead branches attached to living trees. Standing or suspended dead wood is generally drier and decays more slowly than wood in contact with the ground (Jomura et al., 2008), possibly reducing the abundance and diversity of insects present (Larkin and Elbourn, 1964). Several studies from Europe support this notion (Jonsell and Weslien, 2003; Gibb et al., 2006; McGeoch et al., 2007; Hjältén et al., 2007; Franc, 2007). However, many threatened species and other insects appear to favor snags (Jonsell et al., 1998; SverdrupThygeson and Ims, 2002; Kappes and Topp, 2004; Hedgren and Schroeder, 2004). Unfortunately, previous efforts to sample from snags have generally limited sampling to within a few meters of the ground. Until the upper reaches of snags are adequately sampled, it will be impossible to reach definite conclusions regarding the relative importance of snags and logs. Here we compare the beetle communities inhabiting snags and logs from base to crown to better understand the relative importance of these two habitats in southeastern forests. We predicted that overall species richness would be higher in logs than in snags based on previous research and on the idea that the upper bole sections and crowns of snags would be less accessible and therefore less readily colonized than those of logs.

\section{Methods}

\subsection{Study site}

This research took place on the 80,267-ha Savannah River Site (SRS) located in the upper Coastal Plain Physiographic Province of South Carolina. The SRS, a facility owned and operated by the United States Department of Energy, was established in 1951, and was designated a National Environmental Research Park in 1972 (Kilgo and Blake, 2005). Most of the land now owned by the Savannah River site was formerly used for agricultural purposes and most forests currently standing were planted or regenerated in the early 1950s (Kilgo and Blake, 2005).

The SRS is somewhat typical of the southeastern coastal plain in that it is dominated (68\%) by pine forests growing on relatively dry upland sites and by mixed hardwoods (22\%) occupying swamps and riparian bottomlands (Kilgo and Blake, 2005). However, the upland and bottomland sites do not consist purely of pines and hardwoods, respectively. At least three tree species are relatively common in both forest types. Sweetgum (Liquidambar styraciflua L.) and water oak (Quercus nigra L.) grow most commonly on mesic sites dominated by mixed hardwoods but also appear sporadically among pines on dry upland sites. Similarly, loblolly pine (Pinus taeda $\mathrm{L}$.) is currently the dominant pine species growing in upland pine forests but was historically restricted to moist bottomland sites (Schultz, 1997) and continues to grow there at low densities. Kilgo and Blake (2005) provide percent basal areas for tree species in different forest types on the Savannah River Site. For a shortleafloblolly pine slope, comparable to the upland forest used in this study, Pinus (taeda and echinata), L. styraciflua and Q. nigra made up $80 \%, 2 \%$ and $1 \%$ of the total basal area, respectively. In contrast, the average percent basal areas in bottomland forests bordering rivers and large streams for P. taeda, L. styraciflua and Q. nigra were $2.2 \%$, $10.6 \%$ and 3.5\%, respectively (Kilgo and Blake, 2005).

The upland and bottomland forests used in this study were approximately $25 \mathrm{~km}$ apart. One Hobo Data Logger was placed in each forest type for approximately one year (2006-2007) to record temperature and humidity. On average, the upland forest was warmer than the bottomland forest ( 18.8 and $17.8^{\circ} \mathrm{C}$, respectively) whereas relative humidity was on average lower there than in the bottomland forest ( 72.2 and $76.6 \%$, respectively). These differences were most pronounced during the growing season (Fig. 1).

\subsection{Experimental design}

Our sampling followed a $2 \times 3 \times 2$ factorial design with the respective factors being forest type (upland pine forest vs. bottomland hardwood forest), tree species ( $L$. styraciflua vs. P. taeda vs. $Q$. nigra), and posture (log vs. snag). There were three replicates.

On June 5-6, 2006, we created 9 snags and 9 logs in the upland sites and the same number in the bottomland sites, equally divided among L. styraciflua, P. taeda, and Q. nigra (i.e., three snags and logs of each species at each site). Snags were created by girdling the trees to a depth of $3 \mathrm{~cm}$ or more using a chainsaw and spraying full strength (53.8\%) glyphosate (Foresters ${ }^{(\mathbb{R})}$, Riverdale Chemical Company, Burr Ridge, IL, USA) into the wounds. To prevent the herbicide from traveling up the tree and possibly affecting insect colonization, a second girdle was created about $15 \mathrm{~cm}$ above the first before herbicide was applied. Only the lower girdle was treated. All girdled trees examined two weeks after treatment were dead.

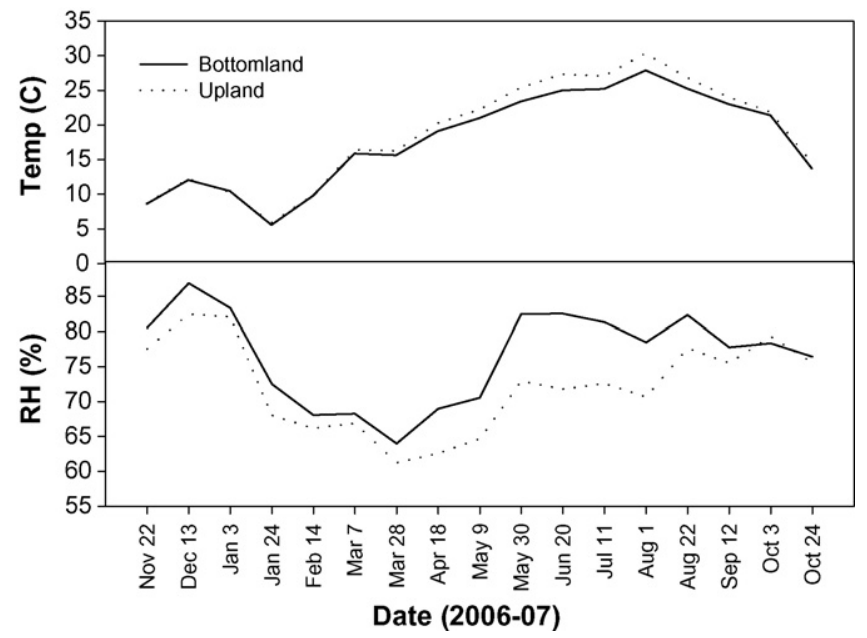

Fig. 1. Temperature and relative humidity over time for a bottomland hardwood forest and an upland pine-dominated stand in South Carolina, USA. 
Approximately 11 months later, in May 2007, we returned to collect sections from the three logs and snags of each species at each site. After felling the snags with chainsaws, we removed $0.5 \mathrm{~m}$ sections from the lower bole, middle bole, and upper bole of each snag and $\log$. The position of each section was measured from the tree base (Appendix A). We also collected three $0.5 \mathrm{~m}$ crown sections taken from major limbs or sometimes the upper-most portion of the main bole. The tops of all but one of the sweetgum snags had broken, so those crown sections had been in contact with the ground for an unknown length of time. The upper bole sections from these trees were taken directly below the point of breakage. All the other snags were intact. All bole and crown sections cut on a given day (May 3 and 8 for upland and bottomland forests, respectively) were labeled and transported to Athens, Georgia.

We recorded the diameter (measured at the center) and bark coverage (visual estimation) of each bole and crown section (Appendix A) in the laboratory. We used these data to calculate the total surface area (not including ends) and bark surface area (product of surface area and visual estimate of bark coverage) sampled from each snag and log.

\subsection{Insect rearing}

Emerging beetles were collected in the laboratory using rearing bags. Rearing bags have been shown to be one of the most efficient methods for collecting saproxylic beetles from dead wood (Jonsell and Hansson, 2007). Bole (108) and crown sections (36) (i.e., the three branch sections from each tree were tied together) were suspended from wooden beams with synthetic rope and enclosed within large (170 l) extra-strength black plastic trash bags. In one bottom corner of each bag we attached a clear plastic collecting jar containing propylene glycol. To prevent mold problems, we continuously ventilated the bags using an electric blower (HADP9-1 Cast Aluminum Pressure Blower, Americraft Manufacturing Co., Cincinnati, OH, USA). Air from the blower flowed through a plastic PVC pipe $(\sim 10 \mathrm{~cm}$ in diameter) that ran the length of the rearing facility near the ceiling. Each side of the pipe had rows of holes into which were inserted sections of clear vinyl tubing $(0.95 \mathrm{~cm}$ o.d., $0.64 \mathrm{~cm}$ i.d.). Each section of tubing led from the pipe to one of the rearing bags. The bags became inflated with air, thus forming effective funnels. Excess air escaped through a single small hole $(\sim 2 \mathrm{~mm})$ drilled near the top of each collecting jar. Overhead fluorescent lights were left on at all times. We did not attempt to control temperature or humidity in the rearing facility, but all samples experienced the same conditions. Screened windows were opened along both sides of the facility to allow for air movement and to match ambient conditions as closely as possible. However, it was typically warmer inside the facility than outside. Samples were collected about once a month for 20 weeks (4 May-21 September and 9 May-26 September for upland and bottomland samples, respectively) and transferred to $70 \%$ ethanol. Beetles were identified using the classification system of Arnett and Thomas $(2001,2002)$. Voucher specimens have been deposited in the Georgia Museum of Natural History, Athens, Georgia.

\subsection{Data analysis}

To test whether there were any differences in the amount of surface area sampled, we conducted a three-way analysis of variance with total surface area sampled (summed for each log or snag) as the response variable. The analysis was repeated for total bark surface area sampled.

Bole and crown samples from each snag or log were combined before conducting an analysis of covariance on a three-way factorial design (SAS Institute, 1990). Surface area and bark surface area were the covariates and the main effects were forest type, tree species and wood posture. All effects were fixed and there were no missing or incomplete samples.

Species richness estimates, based on the Chao1 estimator, were calculated using EstimateS (Colwell, 2006). The Chao1 estimator is calculated as follows: Chao1 $=S_{\mathrm{obs}}+\left(a^{2} / 2 b\right)$ where $S_{\mathrm{obs}}$ is the observed species richness, $a$ is the number of singletons and $b$ is the number of doubletons (Colwell and Coddington, 1994). This is an appropriate estimator for this study given that Chao1 is thought to perform well on large datasets with large numbers of rare species (Colwell and Coddington, 1994, and references therein). Species richness estimates are useful because, by factoring in species rarity, they give an indication of how thoroughly an assemblage of species has been sampled. Because it is possible for observed richness trends to differ from estimated richness trends, it is useful to examine both.

Indicator species analysis (Dufrêne and Legendre, 1997) was performed four times using PC-ORD (McCune and Mefford, 2006) to determine which species were significantly associated with (1) upland or bottomland forests; (2) snags or logs; (3) oak, pine or sweetgum; (4) lower bole, middle bole, upper bole or crown. Indicator values ranging from 0 (no association) to 100 (perfect association) were tested for statistical significance using a Monte Carlo randomization with 2500 permutations (McCune and Grace, 2002).

\section{Results and discussion}

\subsection{Data set}

Overall, 33,457 specimens from 52 families and 250 "species" emerged over the $20 \mathrm{wk}$ sampling period (Appendix B). An effort was made to identify all specimens to the lowest taxonomic units possible given available time and expertise. All specimens were identified to family, $79 \%$ were identified to genus and 59\% were identified to species. Several species rich groups (e.g., Ciidae, Corylophidae and Ptiliidae) were not sorted below family level and were treated as single taxonomic units even though they likely consisted of multiple species. The estimates of species richness presented in this paper are therefore conservative. At least one undescribed species, a histerid belonging to the genus Bacanius, was collected in this study (A. Tishechkin, personal communication).

\subsection{Surface area and bark surface area}

Surface area did not vary significantly for any of the factors (data not shown). However, bark surface area varied significantly among tree species $\left(F_{2,24}=31.30, P<0.0001\right)$, being lower for $P$. taeda than for $Q$. nigra and $L$. styraciflua. There was also a significant interaction between tree species and posture $\left(F_{2,24}=9.6, P=0.0009\right)$ due to the fact that $P$. taeda snags had considerably less bark than $P$. taeda logs $\left(0.55 \pm 0.12\right.$ and $1.22 \pm 0.14 \mathrm{~m}^{2}$, respectively).

\subsection{Species richness and habitat associations}

Overall, species richness differed significantly between forest types and wood postures but not among tree species (Table 1). Because there were no significant interaction terms (Table 1 ), the results for each factor are discussed individually below.

1. Forest type. In total, 189 and 175 beetle species were collected from the upland and bottomland forests, respectively. Mean species richness was significantly higher in the upland forest than the bottomland forest (Fig. 2A). We attribute this to differences in light intensity and temperature between the two forest types. The upland pine-dominated forest was more open 
Table 1

Results from an analysis of covariance on the three-way factorial design.

\begin{tabular}{lrrrl}
\hline Source & df & \multicolumn{1}{c}{ MS } & \multicolumn{1}{l}{$F$} & $P$ \\
\hline Forest type & 1 & 185.83 & 4.62 & 0.04 \\
Tree species & 2 & 112.03 & 2.78 & 0.08 \\
Wood posture & 1 & 262.53 & 6.52 & 0.02 \\
Forest type $\times$ tree species & 2 & 68.81 & 1.71 & 0.20 \\
Forest type $\times$ wood posture & 1 & 30.84 & 0.77 & 0.39 \\
Tree species $\times$ wood posture & 2 & 15.86 & 0.39 & 0.68 \\
Forest type $\times$ tree species $\times$ posture & 2 & 0.10 & 0.00 & 1.00 \\
Surface area (covariate) & 1 & 117.67 & 2.92 & 0.10 \\
Bark surface area (covariate) & 1 & 0.45 & 0.01 & 0.92 \\
Error & 22 & 40.26 & & \\
Total & 35 & & & \\
\hline
\end{tabular}

and sun-exposed than the bottomland hardwood forest and was consequently warmer and less humid (Fig. 1). A number of studies have shown that sun-exposure promotes saproxylic beetle diversity (Bouget and Duelli, 2004, and references therein). For example, most saproxylic beetle species in Sweden, including $59 \%$ of those red-listed, can tolerate and often prefer sun-exposed conditions (Jonsell et al., 1998; Lindhe et al., 2005).

The two forest types supported fairly distinct communities even though we sampled the same tree species in both. Indicator species analysis determined that 15 and 9 species were significantly associated with the upland and bottomland forests, respectively (Appendix $B$ ).

Further research is needed to better understand how and why saproxylic beetle communities differ between forest types. Fire frequency differs considerably between upland and bottomland forests and may be particularly important in shaping saproxylic beetle communities in the southeastern United States. For example, the frequent fires characteristic of upland forests may favor many pyrophilic species as they do in other regions (Evans, 1966; Moretti et al., 2004). Also, frequent fires may select for enhanced dispersal abilities. Beetles in upland fire-prone forests may need to flee fires and re-colonize burned areas regularly compared to those in bottomland forests. This question has important implications with respect to the dead wood connectivity required in different forest types (Grove, 2006).

2. Tree species. There were no significant differences in beetle richness among tree species (Table 1 ). The observation that considerably fewer species emerged from $P$. taeda than $L$. styraciflua (Fig. 2B) may be attributed in part to the fact that bark surface area, a covariate in our model, was significantly lower for

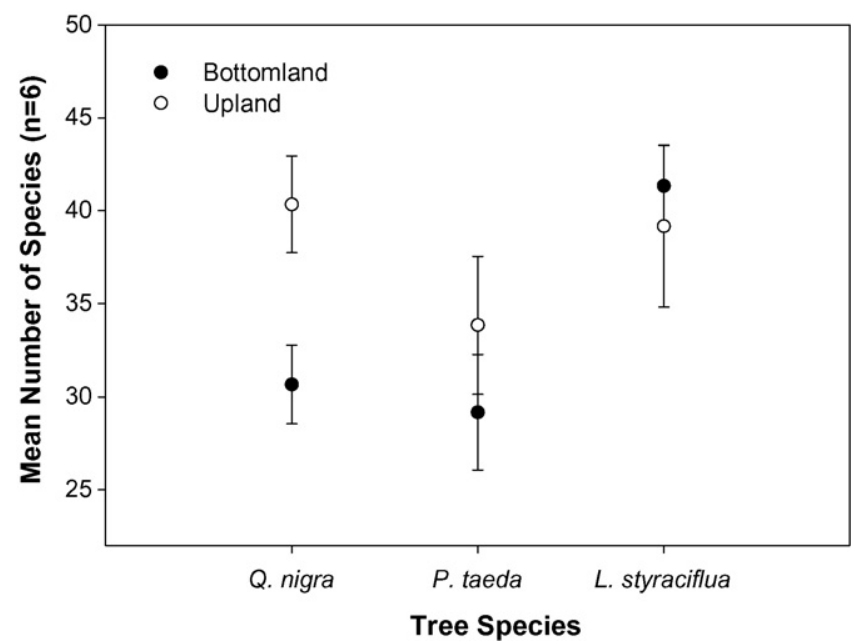

Fig. 3. Mean $( \pm$ SE) number of saproxylic beetle species collected from wood in upland and bottomland forests for each of three tree species in South Carolina, USA.

P. taeda than for L. styraciflua. However, because 152 species emerged from $L$. styraciflua, compared to just 122 and 125 species from $Q$. nigra and $P$. taeda, respectively, L. styraciflua may be of particular importance to early-successional saproxylic beetles in the southeastern United States.

The interaction between tree species and forest type was not significant (Table 1) even though tree abundances differed considerably between upland and bottomland forests. We expected more species would emerge from $Q$. nigra and L. styraciflua in the bottomland than in the upland forest because those species are much more common in bottomland forests. Similarly, we expected $P$. taeda to support more species rich assemblages in the upland forest where that species is more abundant. The observed trends were not consistent with these expectations (Fig. 3). For example, $Q$ nigra yielded, on average, about 10 more beetle species in the upland pine-dominated stand than in the bottomland hardwood forest (Fig. 3). The expected species richness trends also did not follow the anticipated pattern (Fig. 4).

Recent findings from Germany corroborate our results. Müller and Goßner (2007) sampled saproxylic beetles in the crowns of oaks in both beech-dominated and oak-dominated forests. They found no difference in the proportion of oak specialists between forest types. Furthermore, there was only a weak relationship between the proportion of oak specialists captured and surrounding oak density.

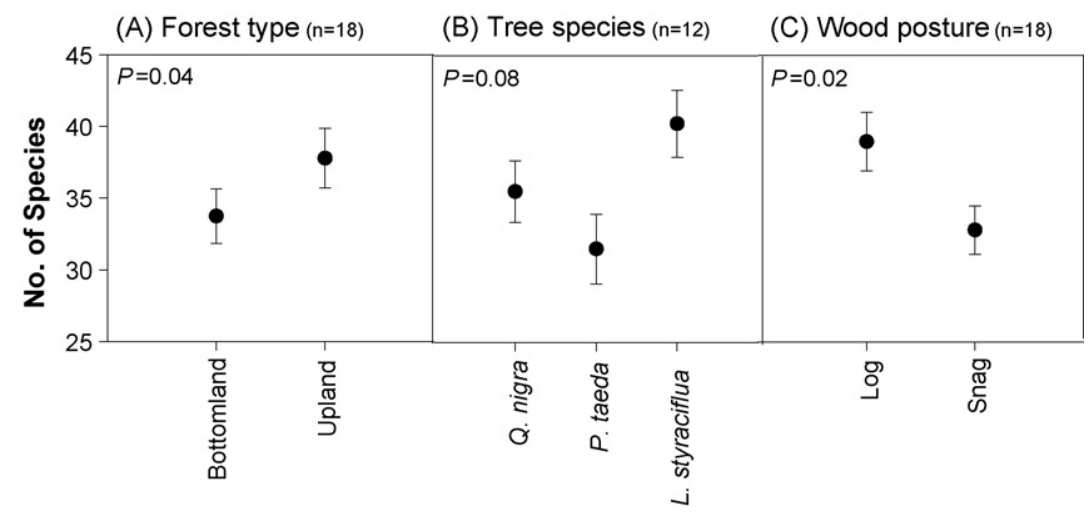

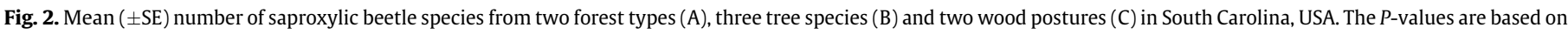
an analysis of covariance for the three-way factorial design (Table 1). 


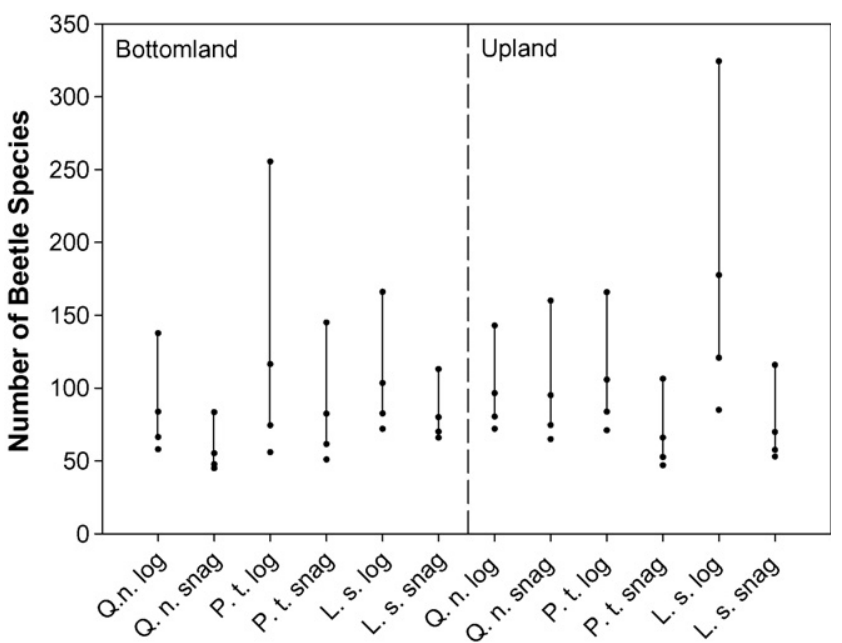

Fig. 4. Lower dots indicate observed total numbers of beetle species collected from $\sim 11$ month-old logs and snags of three tree species (Q. nigra, P. taeda and $L$. styraciflua) in South Carolina, USA. Above these are the mean $(n=3)$ Chao1 species richness estimates with $95 \%$ confidence limits. Sampling took place in both a mixed bottomland hardwood forest (left) and an upland pine-dominated stand (right).

Our results show relative tree abundance is not a good predictor of beetle species richness and the seemingly minor hardwood components on upland sites are of considerable importance to the saproxylic beetle community. This may be particularly true for the hardwood-dominated drainages frequently embedded within upland pine stands in the southeastern United States. These may be areas of high saproxylic beetle diversity that provide refuge for saproxylic beetles during fires. They might also greatly enhance habitat connectivity for species associated with hardwoods.

3. Wood posture. In total, 194 and 171 species emerged from logs and snags, respectively. Mean species richness was significantly higher in logs than in snags (Fig. 2C). Similarly, species richness estimates were consistently higher for logs regardless of tree species and forest type (Fig. 4). These differences are consistent with previous studies (Jonsell and Weslien, 2003; Gibb et al., 2006; McGeoch et al., 2007; Hjältén et al., 2007; Franc, 2007) and probably widen with time, particularly as the snags become dry following bark loss (Boulanger and Sirois, 2007).

Although snags support fewer beetle species than logs, it is clear from our results that a number of species specifically require snags. Using indicator species analysis, we found 12 species were significantly associated with snags and 18 species were significantly associated with logs (Appendix B). A number of the snagassociated species were primarily collected from the upper-most portions of snags. For example, Tenebroides semicylindricus (Trogossitidae) was found to be significantly associated with the crowns of snags (Appendix B). Similarly, almost all specimens of Germarostes (Ceratocanthidae) were collected from mid-bole or higher, including five specimens from crown sections. We also found evidence of vertical stratification among cossonine weevil genera. While the most common genus, Cossonus, was concentrated near the ground and was not significantly associated with snags, two other genera, Rhyncolus and Stenoscelis, were significant snag associates and were collected most commonly from the upper-most bole sections (Fig. 5).

Based on our results and those of previous studies, snags appear vital to maintaining a complete saproxylic beetle community. Although logs support more species rich beetle assemblages and have their own specialist species, our data and others suggest

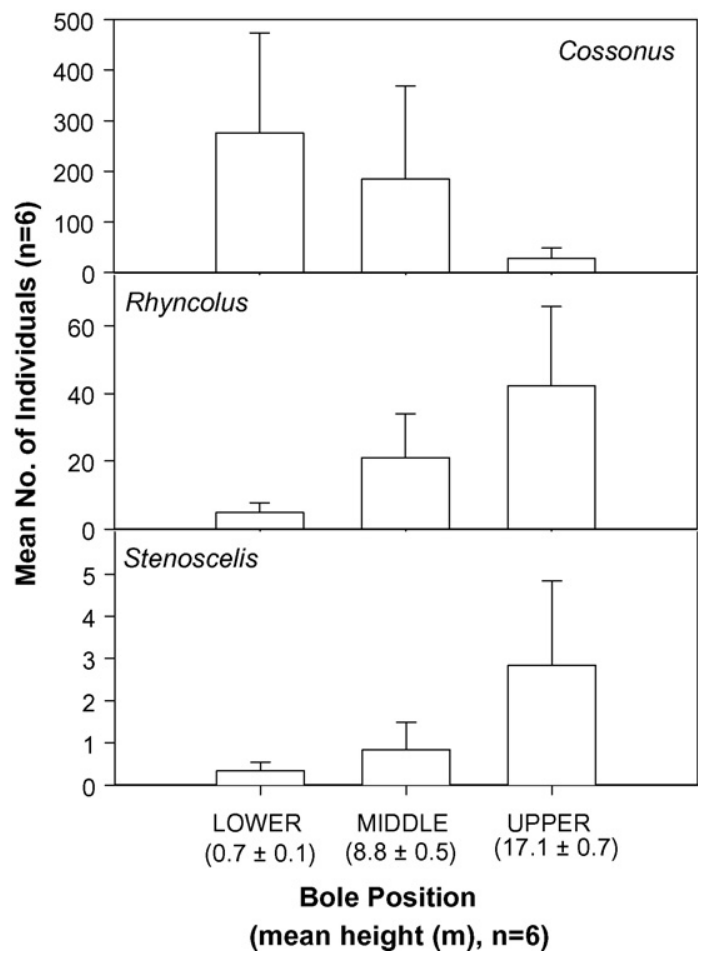

Fig. 5. Vertical distribution patterns of the three most common Cossoninae (Curculionidae) genera collected from pine snags in South Carolina, USA.

snags are more important than logs for conservation purposes. First, research from Scandinavia suggests that most saproxylic beetle species can live within standing dead wood and that snags support more threatened species than logs (Jonsell et al., 1998; Franc, 2007, and references therein). Second, snags become logs as soon as they fall, usually within 5 yrs for pine in the southeastern US (Moorman et al., 1999; Conner and Saenz, 2005), thereby providing habitats for both snag and log-associated beetles. Third, logging slash, if left on site, should provide adequate habitat for many species associated with logs. Finally, snags are also required by a wide variety of cavity-nesting birds and other vertebrates of conservation concern (Lohr et al., 2002).

\section{Conclusions}

In this study we examined the saproxylic beetle community at a single point in time, approximately 11 months after tree death. Our results may have differed considerably had we sampled earlier or later during the decades-long processes of wood decay and insect succession. However, we suspect that the disparity in species richness between snags and logs, with snags supporting fewer species than logs, widens with time following tree death. Snags become increasingly drier than logs with time and, as a consequence, likely become less suitable to many saproxylic organisms. This was demonstrated by Boulanger and Sirois (2007) in a study of post-fire succession in Canada. The researchers found an absence of beetle succession on black spruce snags following bark loss. Only after the snags fell to the ground did succession proceed. The authors attribute their findings to differences in moisture and accessibility between snags and logs. Although some beetle species may specialize on snags at advanced stages of decay, it seems likely that most snag associates are early-successional given the rapid decay rates of wood and the short longevities of snags (Moorman et al., 1999; Conner and Saenz, 2005) in the southeastern United States. 
Based on the three tree species sampled in this study, our results indicate that upland forests support more saproxylic beetle species than bottomland forests. However, bottomland forests support many tree species absent from upland forests and may have more saproxylic beetle species overall. We plan to further address this question in a future paper using data from flight intercept traps.

This research provides some important insights into the habitat associations and requirements of saproxylic beetles in the southeastern United States. However, further study is needed to better understand the status of saproxylic beetles throughout the region. Comparisons between old-growth and managed forests would be of particular value in determining whether or not species are declining or have disappeared from managed forests.

\section{Acknowledgements}

We wish to thank Scott Horn and Mike Cody for assisting with field work, Bob Rabaglia and Alexey Tishechkin for identifying scolytines and histerids, respectively, and Cecil Smith and Mike Thomas for their assistance and hospitality during visits to the Georgia Museum of Natural History and the Florida State Collection of Arthropods, respectively. We also thank two anonymous reviewers for suggestions that greatly improved the manuscript. Support was provided by the Department of EnergySavannah River Operations Office through the U.S. Forest Service Savannah River under Interagency Agreement DE-AI0900SR22188.

\section{Appendix A}

Data (mean $\pm \mathrm{SE}, n=3$ ) collected from $0.5 \mathrm{~m}$ wood samples taken from 11 month-old logs and snags of three tree species ( $Q$. nigra L., $P$. taeda L. and L. styraciflua L.) in South Carolina, USA. The samples were taken at four positions from each log and snag: lower bole, middle bole, upper bole and crown. Data from the three crown sections were summed. Surface area calculations do not include the ends of the logs. Bark surface area equals the product of surface area and \%bark coverage (a visual estimate).

\begin{tabular}{|c|c|c|c|c|c|c|c|c|}
\hline & \multicolumn{2}{|c|}{ Distance from tree base (m) } & \multicolumn{2}{|c|}{ Diameter (m) } & \multicolumn{2}{|c|}{ Surface area $\left(\mathrm{m}^{2}\right)$} & \multicolumn{2}{|c|}{ Bark surface area $\left(\mathrm{m}^{2}\right)$} \\
\hline & Logs & Snags & Logs & Snags & Logs & Snags & Logs & Snags \\
\hline \multicolumn{9}{|l|}{ Bottomland } \\
\hline Q. n. lower & $0.85 \pm 0.23$ & $0.68 \pm 0.04$ & $0.36 \pm 0.01$ & $0.35 \pm 0.02$ & $0.56 \pm 0.02$ & $0.55 \pm 0.03$ & $0.56 \pm 0.02$ & $0.55 \pm 0.03$ \\
\hline Q. $n$. middle & $7.83 \pm 0.14$ & $8.42 \pm 0.16$ & $0.26 \pm 0.01$ & $0.27 \pm 0.01$ & $0.42 \pm 0.02$ & $0.42 \pm 0.02$ & $0.42 \pm 0.02$ & $0.42 \pm 0.02$ \\
\hline Q. n. upper & $14.78 \pm 0.34$ & $15.33 \pm 0.50$ & $0.20 \pm 0.00$ & $0.20 \pm 0.01$ & $0.31 \pm 0.01$ & $0.31 \pm 0.01$ & $0.31 \pm 0.01$ & $0.29 \pm 0.03$ \\
\hline Q. n. crown & - & - & $0.25 \pm 0.02$ & $0.24 \pm 0.02$ & $0.39 \pm 0.03$ & $0.38 \pm 0.03$ & $0.39 \pm 0.03$ & $0.38 \pm 0.03$ \\
\hline P.t. lower & $0.52 \pm 0.08$ & $0.75 \pm 0.14$ & $0.36 \pm 0.01$ & $0.37 \pm 0.04$ & $0.57 \pm 0.01$ & $0.58 \pm 0.06$ & $0.54 \pm 0.04$ & 0 \\
\hline P.t. middle & $9.97 \pm 0.80$ & $9.69 \pm 0.84$ & $0.28 \pm 0.01$ & $0.31 \pm 0.04$ & $0.43 \pm 0.02$ & $0.49 \pm 0.06$ & $0.42 \pm 0.02$ & $0.28 \pm 0.17$ \\
\hline P.t. upper & $19.40 \pm 0.95$ & $18.11 \pm 1.24$ & $0.19 \pm 0.01$ & $0.22 \pm 0.03$ & $0.29 \pm 0.01$ & $0.35 \pm 0.04$ & $0.19 \pm 0.09$ & 0 \\
\hline P.t. crown & - & - & $0.23 \pm 0.01$ & $0.21 \pm 0.01$ & $0.36 \pm 0.01$ & $0.33 \pm 0.01$ & $0.21 \pm 0.04$ & $0.10 \pm 0.02$ \\
\hline L.S. lower & $0.99 \pm 0.24$ & $0.97 \pm 0.04$ & $0.32 \pm 0.04$ & $0.40 \pm 0.02$ & $0.50 \pm 0.07$ & $0.64 \pm 0.03$ & $0.50 \pm 0.07$ & $0.64 \pm 0.03$ \\
\hline L.s. middle & $7.32 \pm 0.12$ & $9.11 \pm 0.86$ & $0.24 \pm 0.02$ & $0.29 \pm 0.03$ & $0.38 \pm 0.04$ & $0.46 \pm 0.04$ & $0.37 \pm 0.04$ & $0.40 \pm 0.03$ \\
\hline L.s. upper & $14.17 \pm 1.35$ & $17.60 \pm 1.83$ & $0.19 \pm 0.04$ & $0.19 \pm 0.01$ & $0.30 \pm 0.06$ & $0.30 \pm 0.01$ & $0.29 \pm 0.08$ & $0.30 \pm 0.01$ \\
\hline L.s. crown & - & - & $0.25 \pm 0.03$ & $0.23 \pm 0.02$ & $0.40 \pm 0.04$ & $0.36 \pm 0.03$ & $0.40 \pm 0.04$ & $0.32 \pm 0.05$ \\
\hline \multicolumn{9}{|l|}{ Upland } \\
\hline Q. n. lower & $0.66 \pm 0.09$ & $0.81 \pm 0.14$ & $0.33 \pm 0.02$ & $0.39 \pm 0.04$ & $0.51 \pm 0.03$ & $0.62 \pm 0.07$ & $0.38 \pm 0.09$ & $0.62 \pm 0.07$ \\
\hline Q. n. middle & $4.84 \pm 0.72$ & $5.01 \pm 0.15$ & $0.26 \pm 0.03$ & $0.27 \pm 0.02$ & $0.41 \pm 0.05$ & $0.42 \pm 0.03$ & $0.37 \pm 0.05$ & $0.42 \pm 0.03$ \\
\hline Q. n. upper & $8.78 \pm 0.42$ & $8.45 \pm 0.38$ & $0.19 \pm 0.03$ & $0.21 \pm 0.02$ & $0.30 \pm 0.04$ & $0.33 \pm 0.04$ & $0.24 \pm 0.07$ & $0.33 \pm 0.04$ \\
\hline Q. n. crown & - & - & $0.24 \pm 0.03$ & $0.23 \pm 0.02$ & $0.38 \pm 0.04$ & $0.37 \pm 0.04$ & $0.36 \pm 0.05$ & $0.37 \pm 0.04$ \\
\hline P.t. lower & $0.97 \pm 0.38$ & $0.73 \pm 0.08$ & $0.36 \pm 0.01$ & $0.35 \pm 0.02$ & $0.57 \pm 0.02$ & $0.55 \pm 0.03$ & $0.23 \pm 0.12$ & $0.38 \pm 0.19$ \\
\hline P.t. middle & $8.27 \pm 1.05$ & $7.90 \pm 0.32$ & $0.31 \pm 0.02$ & $0.28 \pm 0.01$ & $0.49 \pm 0.03$ & $0.44 \pm 0.02$ & $0.25 \pm 0.14$ & $0.05 \pm 0.05$ \\
\hline P.t. upper & $16.05 \pm 1.78$ & $16.00 \pm 0.67$ & $0.26 \pm 0.02$ & $0.23 \pm 0.00$ & $0.40 \pm 0.03$ & $0.35 \pm 0.00$ & $0.34 \pm 0.04$ & $0.14 \pm 0.09$ \\
\hline P.t. crown & - & - & $0.20 \pm 0.02$ & $0.23 \pm 0.01$ & $0.31 \pm 0.03$ & $0.35 \pm 0.02$ & $0.28 \pm 0.04$ & $0.15 \pm 0.05$ \\
\hline L.S. lower & $0.55 \pm 0.03$ & $0.83 \pm 0.11$ & $0.35 \pm 0.01$ & $0.31 \pm 0.02$ & $0.54 \pm 0.02$ & $0.48 \pm 0.02$ & $0.54 \pm 0.02$ & $0.48 \pm 0.02$ \\
\hline L.s. middle & $5.24 \pm 0.74$ & $5.00 \pm 0.28$ & $0.26 \pm 0.02$ & $0.23 \pm 0.01$ & $0.40 \pm 0.03$ & $0.36 \pm 0.02$ & $0.40 \pm 0.03$ & $0.36 \pm 0.02$ \\
\hline L.s. upper & $10.13 \pm 1.43$ & $8.88 \pm 0.54$ & $0.20 \pm 0.02$ & $0.18 \pm 0.01$ & $0.32 \pm 0.03$ & $0.28 \pm 0.02$ & $0.32 \pm 0.03$ & $0.28 \pm 0.02$ \\
\hline L.S. crown & - & - & $0.22 \pm 0.01$ & $0.24 \pm 0.01$ & $0.35 \pm 0.02$ & $0.37 \pm 0.02$ & $0.35 \pm 0.02$ & $0.37 \pm 0.02$ \\
\hline
\end{tabular}

\section{Appendix B}

List of beetles collected from logs and snags of three tree species in two forest types at the Savannah River Site, South Carolina, USA. Abundances are presented in terms of logs/snags. Associations are based on significant indicator values for (1) snags or logs; (2) upland or bottomland; (3) oak, pine, or sweetgum; and (4) bole position (lower, middle, upper or crown) with asterisks denoting significance: ${ }^{*} P<0.05$, ${ }^{* *} P<0.01,{ }^{* * *} P<0.001$.

\begin{tabular}{|c|c|c|c|c|c|c|c|c|}
\hline \multirow[t]{2}{*}{ Family/species } & \multirow{2}{*}{$\begin{array}{l}\text { Association(s) } \\
\text { (indicator value) }\end{array}$} & \multicolumn{3}{|c|}{ Bottomland } & \multicolumn{3}{|c|}{ Upland } & \multirow[t]{2}{*}{ Total } \\
\hline & & Oak & Pine & Sweetgum & Oak & Pine & Sweetgum & \\
\hline \multicolumn{9}{|l|}{ Aderidae } \\
\hline Cnopus impressus (LeConte) & Middle bole $\left(17.8^{* * *}\right)$; & $0 / 0$ & $5 / 3$ & $0 / 0$ & $0 / 0$ & $3 / 0$ & $1 / 0$ & 12 \\
\hline Ganascus ptinoides (Schwarz) & pine $\left(13.4^{* *}\right)$ & $0 / 0$ & $4 / 0$ & $1 / 0$ & $0 / 0$ & $0 / 0$ & $0 / 0$ & 5 \\
\hline Ganascus ventricosus (LeConte) & & $0 / 0$ & $1 / 0$ & $2 / 0$ & $0 / 1$ & $5 / 0$ & $0 / 0$ & 9 \\
\hline \multicolumn{9}{|l|}{ Anobiidae } \\
\hline Lasioderma sp. & & $1 / 0$ & $0 / 0$ & $0 / 0$ & $1 / 3$ & $0 / 0$ & $0 / 0$ & 5 \\
\hline
\end{tabular}


Appendix B (Continued)

\begin{tabular}{|c|c|c|c|c|c|c|c|c|}
\hline \multirow[t]{2}{*}{ Family/species } & \multirow{2}{*}{$\begin{array}{l}\text { Association(s) } \\
\text { (indicator value) }\end{array}$} & \multicolumn{3}{|c|}{ Bottomland } & \multicolumn{3}{|c|}{ Upland } & \multirow[t]{2}{*}{ Total } \\
\hline & & Oak & Pine & Sweetgum & Oak & Pine & Sweetgum & \\
\hline Petalium sp. & $\begin{array}{l}\text { Bottomland }\left(19.3^{* *}\right) \text {; } \\
\text { sweetgum }\left(34.8^{* * *}\right)\end{array}$ & $0 / 0$ & $0 / 1$ & $30 / 20$ & $0 / 0$ & $0 / 0$ & $1 / 3$ & 55 \\
\hline Tricorynus sp. & $\begin{array}{l}\text { Middle bole }\left(11^{*}\right) ; \\
\text { sweetgum }\left(12.5^{* *}\right)\end{array}$ & $0 / 0$ & $0 / 0$ & $15 / 3$ & $0 / 0$ & $0 / 0$ & $1 / 0$ & 19 \\
\hline Piesocorynus sp. & $\begin{array}{l}\text { Oak }\left(14.3^{* *}\right) \\
\log \left(9.5^{*}\right)\end{array}$ & $7 / 0$ & $0 / 0$ & $0 / 1$ & $38 / 0$ & $0 / 0$ & $0 / 0$ & 46 \\
\hline $\begin{array}{l}\text { Biphyllidae } \\
\text { Diplocoelus rudis (LeConte) }\end{array}$ & & $0 / 0$ & $0 / 0$ & $0 / 0$ & $1 / 0$ & $2 / 0$ & $3 / 0$ & 6 \\
\hline $\begin{array}{l}\text { Bostrichidae } \\
\text { Lichenophanes sp. }\end{array}$ & & $0 / 0$ & $0 / 0$ & $0 / 0$ & $2 / 0$ & $0 / 0$ & $0 / 0$ & 2 \\
\hline \multicolumn{9}{|l|}{ Bothrideridae } \\
\hline Arrenodes minutus (Drury) & & $8 / 2$ & $0 / 0$ & $7 / 0$ & $0 / 12$ & $0 / 0$ & $0 / 0$ & 29 \\
\hline \multicolumn{9}{|l|}{ Buprestidae } \\
\hline Agrilus sp. & Oak $\left(8.3^{*}\right)$ & $1 / 0$ & $0 / 0$ & $0 / 0$ & $0 / 5$ & $0 / 0$ & $0 / 0$ & 6 \\
\hline Buprestis lineata Fabricius & & $0 / 0$ & $0 / 2$ & $0 / 0$ & $0 / 0$ & $0 / 0$ & $0 / 0$ & 2 \\
\hline Chrysobothris femorata Olivier & & $2 / 0$ & $0 / 0$ & $0 / 0$ & $1 / 0$ & $0 / 0$ & $0 / 1$ & 4 \\
\hline Chrysobothris sexsignata (Say) & & $0 / 1$ & $0 / 0$ & $0 / 0$ & $0 / 0$ & $0 / 0$ & $0 / 0$ & 1 \\
\hline \multicolumn{9}{|l|}{ Carabidae } \\
\hline Anillinus sp. & & $0 / 0$ & $1 / 0$ & $0 / 0$ & $0 / 0$ & $0 / 0$ & $0 / 0$ & 1 \\
\hline Coptodera aerata Dejean & & $0 / 1$ & $0 / 0$ & $0 / 0$ & $0 / 0$ & $0 / 0$ & $0 / 0$ & 1 \\
\hline Mioptachys flavicauda (Say) & $\begin{array}{l}\text { Lower bole }\left(45.3^{* * *}\right) \text {; } \\
\log \left(29.4^{*}\right)\end{array}$ & $8 / 0$ & $39 / 23$ & $36 / 94$ & $10 / 0$ & $70 / 5$ & $49 / 6$ & 340 \\
\hline Perigona pallipennis (LeConte) & & $0 / 0$ & $0 / 0$ & $2 / 0$ & $0 / 0$ & $0 / 0$ & $0 / 0$ & 2 \\
\hline Phloeoxena signata (Dejean) & & $0 / 0$ & $1 / 0$ & $0 / 0$ & $0 / 0$ & $0 / 0$ & $1 / 0$ & 2 \\
\hline Astylopsis sexguttata (Say) & & $0 / 0$ & $1 / 0$ & $0 / 0$ & $0 / 0$ & $0 / 0$ & $0 / 0$ & 1 \\
\hline Curius dentatus Newman & & $0 / 0$ & $0 / 0$ & $0 / 0$ & $0 / 0$ & $0 / 0$ & $0 / 3$ & 3 \\
\hline Elaphidion mucronatum (Say) & & $0 / 0$ & $0 / 0$ & $0 / 0$ & $0 / 0$ & $0 / 0$ & $2 / 0$ & 2 \\
\hline Leptostylus asperatus (Haldeman) & Sweetgum $\left(18.7^{* * *}\right)$ & $0 / 0$ & $0 / 0$ & $4 / 0$ & $0 / 0$ & $0 / 0$ & $1 / 14$ & 19 \\
\hline Leptostylus planidorsus (LeConte) & & $0 / 0$ & $0 / 0$ & $0 / 0$ & $0 / 0$ & $0 / 0$ & $1 / 0$ & 1 \\
\hline Lepturges confluens (Haldeman) & Sweetgum $\left(8.3^{*}\right)$ & $0 / 0$ & $0 / 0$ & $0 / 2$ & $0 / 0$ & $0 / 0$ & $0 / 2$ & 4 \\
\hline Liopinus alpha (Say) & Sweetgum (10.4*) & $0 / 0$ & $0 / 0$ & $0 / 0$ & $0 / 0$ & $0 / 0$ & $0 / 13$ & 13 \\
\hline Monochamus carolinensis (Olivier) & & $0 / 0$ & $2 / 0$ & $0 / 0$ & $0 / 0$ & $0 / 1$ & $0 / 0$ & 3 \\
\hline Monochamus titillator (Fabricius) & $\begin{array}{l}\text { Middle bole }\left(17.5^{*}\right) \\
\text { pine }\left(45^{* * *}\right)\end{array}$ & $0 / 0$ & $19 / 17$ & $1 / 0$ & $0 / 0$ & $8 / 9$ & $0 / 0$ & 54 \\
\hline Neoclytus scutellaris (Olivier) & Oak $\left(18.7^{* * * *}\right)$ & $2 / 2$ & $0 / 0$ & $0 / 0$ & $2 / 9$ & $0 / 0$ & $0 / 0$ & 15 \\
\hline Urographis fasciatus (DeGeer) & $\begin{array}{l}\text { Lower bole }\left(26.6^{* *}\right) \text {; } \\
\text { oak }\left(43.7^{* * *}\right)\end{array}$ & $74 / 113$ & $0 / 0$ & $36 / 31$ & $20 / 61$ & $0 / 0$ & $42 / 45$ & 422 \\
\hline Xylotrechus colonus (Fabricius) & $\begin{array}{l}\text { Lower bole }\left(30.1^{* * *}\right) \text {; } \\
\text { oak }\left(23^{* *}\right)\end{array}$ & $7 / 12$ & $1 / 0$ & $4 / 7$ & $3 / 78$ & $0 / 0$ & $13 / 11$ & 136 \\
\hline Xylotrechus sagittatus (Germar) & Pine $\left(61.9^{* * *}\right)$ & $0 / 0$ & $20 / 41$ & $1 / 0$ & $0 / 0$ & $14 / 32$ & $0 / 0$ & 108 \\
\hline \multicolumn{9}{|l|}{ Ceratocanthidae } \\
\hline Germarostes aphodioides (Illiger) & $\begin{array}{l}\text { Oak }\left(14.9^{* *}\right) \\
\text { snag }\left(11.8^{*}\right)\end{array}$ & $1 / 7$ & $0 / 0$ & $0 / 2$ & $0 / 9$ & $0 / 0$ & $0 / 0$ & 19 \\
\hline Germarostes globosus (Say) & & $0 / 4$ & $0 / 0$ & $0 / 0$ & $0 / 0$ & $0 / 0$ & $0 / 0$ & 4 \\
\hline \multicolumn{9}{|l|}{ Cerylonidae } \\
\hline Cerylon unicolor (Ziegler) & $\begin{array}{l}\text { Lower bole }\left(23.7^{* *}\right) \text {; } \\
\text { sweetgum }\left(18.3^{*}\right)\end{array}$ & $1 / 6$ & $1 / 5$ & $19 / 37$ & $0 / 0$ & $5 / 8$ & $12 / 34$ & 128 \\
\hline Hypodacne punctata LeConte & & $0 / 0$ & $0 / 0$ & $1 / 0$ & $0 / 0$ & $0 / 0$ & $0 / 0$ & 1 \\
\hline Murmidius ovalis (Beck) & $\begin{array}{l}\text { Upland }\left(10.8^{*}\right) \\
\text { oak }\left(16.2^{* *}\right)\end{array}$ & $0 / 1$ & $0 / 0$ & $0 / 0$ & $3 / 28$ & $0 / 1$ & $0 / 0$ & 33 \\
\hline Mychocerinus depressus (LeConte) & Snag $\left(8^{*}\right)$ & $0 / 22$ & $0 / 0$ & $0 / 0$ & $0 / 0$ & $0 / 2$ & $1 / 1$ & 26 \\
\hline
\end{tabular}


Appendix B (Continued)

\begin{tabular}{|c|c|c|c|c|c|c|c|c|}
\hline \multirow[t]{2}{*}{ Family/species } & \multirow{2}{*}{$\begin{array}{l}\text { Association(s) } \\
\text { (indicator value) }\end{array}$} & \multicolumn{3}{|c|}{ Bottomland } & \multicolumn{3}{|l|}{ Upland } & \multirow[t]{2}{*}{ Total } \\
\hline & & Oak & Pine & Sweetgum & Oak & Pine & Sweetgum & \\
\hline \multicolumn{9}{|l|}{ Chelonariidae } \\
\hline Chelonarium lecontei Thomson & & $0 / 0$ & $0 / 0$ & $0 / 4$ & $0 / 0$ & $0 / 0$ & $0 / 0$ & 4 \\
\hline \multicolumn{9}{|l|}{ Ciidae } \\
\hline Ciidae spp. & Lower bole $\left(46.5^{* *}\right)$ & $2393 / 419$ & $7 / 0$ & $342 / 98$ & $53 / 293$ & $46 / 4$ & $591 / 447$ & 4693 \\
\hline \multicolumn{9}{|l|}{ Cleridae } \\
\hline Ababa tantilla (LeConte) & & $1 / 0$ & $0 / 0$ & $0 / 0$ & $0 / 0$ & $0 / 0$ & $0 / 0$ & 1 \\
\hline Chariessa pilosa (Forster) & & $1 / 0$ & $0 / 0$ & $0 / 0$ & $1 / 1$ & $0 / 0$ & $0 / 0$ & 3 \\
\hline Cymatodera undulata (Say) & & $0 / 0$ & $0 / 1$ & $0 / 0$ & $0 / 0$ & $0 / 0$ & $0 / 0$ & 1 \\
\hline Neorthopleura thoracica (Say) & Oak (10.4*); crown $\left(10^{*}\right)$ & $2 / 0$ & $0 / 0$ & $0 / 0$ & $7 / 1$ & $0 / 0$ & $0 / 0$ & 10 \\
\hline Priocera castanea (Newman) & & $0 / 0$ & $0 / 5$ & $0 / 0$ & $0 / 0$ & $0 / 2$ & $1 / 0$ & 8 \\
\hline \multicolumn{9}{|l|}{ Colydiidae } \\
\hline Aulonium parallelopipedum (Say) & & $0 / 0$ & $0 / 0$ & $0 / 1$ & $0 / 5$ & $0 / 0$ & $0 / 1$ & 7 \\
\hline Bitoma carinata (LeConte) & $\begin{array}{l}\text { Bottomland }\left(32.1^{* *}\right) \text {; lower } \\
\text { bole }\left(45^{* * *}\right) \text {; oak }\left(27.2^{* *}\right)\end{array}$ & $124 / 74$ & $11 / 4$ & $25 / 100$ & $15 / 28$ & $8 / 0$ & $3 / 32$ & 424 \\
\hline Bitoma quadricollis (Horn) & Oak $\left(18.7^{* * * *}\right) ; \log \left(12.5^{* *}\right)$ & $9 / 0$ & $3 / 0$ & $0 / 0$ & $14 / 3$ & $0 / 0$ & $0 / 0$ & 29 \\
\hline Bitoma quadriguttata (Say) & Upland $\left(38.1^{* * *}\right)$; oak $\left(32.4^{* * *}\right)$ & $8 / 27$ & $0 / 1$ & $6 / 6$ & $50 / 36$ & $2 / 0$ & $20 / 46$ & 202 \\
\hline Colydium lineola Say & $\begin{array}{l}\text { Lower bole }\left(27.2^{*}\right) \text {; } \\
\text { oak }\left(48.3^{* * * *}\right) \text {; snag }\left(50.2^{* *}\right)\end{array}$ & $35 / 205$ & $0 / 0$ & $32 / 304$ & $57 / 471$ & $0 / 0$ & $30 / 157$ & 1291 \\
\hline Colydium nigripenne LeConte & $\begin{array}{l}\text { Lower bole }\left(19.3^{* * *}\right) \text {; } \\
\text { pine }\left(35.1^{* * *}\right)\end{array}$ & $0 / 0$ & $5 / 47$ & $0 / 0$ & $0 / 0$ & $55 / 22$ & $1 / 0$ & 130 \\
\hline Endeitoma dentata (Horn) & & $0 / 0$ & $0 / 0$ & $0 / 0$ & $0 / 0$ & $1 / 0$ & $0 / 0$ & 1 \\
\hline Endeitoma granulata (Say) & & $0 / 0$ & $0 / 1$ & $0 / 0$ & $0 / 0$ & $13 / 0$ & $0 / 0$ & 14 \\
\hline Microsicus parvulus (Guérin-Méneville) & Upland $\left(9.7^{*}\right)$; oak $\left(14.6^{* *}\right)$ & $0 / 0$ & $0 / 0$ & $0 / 0$ & $2 / 9$ & $0 / 0$ & $0 / 0$ & 11 \\
\hline Namunaria guttulata (LeConte) & & $0 / 0$ & $1 / 1$ & $0 / 0$ & $2 / 0$ & $2 / 0$ & $1 / 0$ & 7 \\
\hline Nematidium filiforme Leconte & Oak (43.7***); snag $\left(17.4^{*}\right)$ & 79/302 & $0 / 0$ & $0 / 0$ & $23 / 209$ & $0 / 0$ & $0 / 0$ & 613 \\
\hline Synchita fuliginosa Melsheimer & $\begin{array}{l}\text { Lower bole }\left(40^{* * *}\right) \\
\text { sweetgum }\left(32.9^{* *}\right)\end{array}$ & $26 / 56$ & $1 / 0$ & $12 / 68$ & $59 / 37$ & $0 / 1$ & $183 / 15$ & 458 \\
\hline \multicolumn{9}{|l|}{ Corylophidae } \\
\hline Corylophidae spp. & Oak $\left(57.7^{* * *}\right) ; \log \left(48.8^{* * *}\right)$ & $460 / 2$ & $3 / 2$ & $72 / 4$ & $980 / 69$ & $6 / 3$ & $36 / 1$ & 1638 \\
\hline \multicolumn{9}{|l|}{ Cryptophagidae } \\
\hline Atomaria sp. & & $0 / 0$ & $1 / 0$ & $0 / 1$ & $0 / 0$ & $0 / 0$ & $0 / 0$ & 2 \\
\hline \multicolumn{9}{|l|}{ Curculionidae } \\
\hline Acalles minimus Blatchley & & $1 / 0$ & $0 / 0$ & $0 / 1$ & $0 / 0$ & $0 / 0$ & $0 / 0$ & 2 \\
\hline Caulophilus rufotestaceus (Champion) & & $0 / 0$ & $0 / 0$ & $1 / 0$ & $0 / 0$ & $0 / 0$ & $0 / 0$ & 1 \\
\hline Cossonus spp. & Pine (68.7***) & $0 / 0$ & $225 / 1255$ & $0 / 0$ & $0 / 1$ & $630 / 1672$ & $0 / 0$ & 3783 \\
\hline Dryocoetes autographus (Ratzeburg) & & $0 / 0$ & $0 / 0$ & $11 / 0$ & $0 / 0$ & $0 / 0$ & $0 / 0$ & 11 \\
\hline Dryophthorus americanus Germar & & $0 / 0$ & $8 / 0$ & $4 / 3$ & $0 / 0$ & $4 / 0$ & $0 / 0$ & 19 \\
\hline Dryoxylon onoharaensum (Murayama) & Sweetgum $\left(8.3^{*}\right)$ & $0 / 0$ & $0 / 0$ & $0 / 0$ & $0 / 0$ & $0 / 0$ & $22 / 34$ & 56 \\
\hline Euplatypus compositus (Say) & $\begin{array}{l}\text { Upland }\left(22.8^{*}\right) ; \\
\text { middle bole }\left(23^{* *}\right) \text {; } \\
\text { sweetgum }\left(22.3^{*}\right)\end{array}$ & $9 / 0$ & $0 / 0$ & $564 / 457$ & $1588 / 169$ & $0 / 0$ & $381 / 437$ & 3605 \\
\hline Gnathotrichus materiarius (Fitch) & & $0 / 0$ & $6 / 0$ & $0 / 0$ & $0 / 0$ & $0 / 0$ & $0 / 0$ & 6 \\
\hline Himatium errans LeConte & & $0 / 0$ & $0 / 1$ & $0 / 0$ & $0 / 0$ & $1 / 2$ & $0 / 0$ & 4 \\
\hline Hypothenemus spp. & $\begin{array}{l}\text { Upland }\left(29.9^{* *}\right) \text {; } \\
\text { lower bole }\left(37.5^{* * * *}\right) \text {; } \\
\text { sweetgum }\left(38.8^{* * *}\right)\end{array}$ & $4 / 4$ & $0 / 0$ & $13 / 12$ & $2 / 94$ & $0 / 0$ & $622 / 753$ & 1504 \\
\hline Monarthrum mali (Fitch) & & $0 / 0$ & $0 / 0$ & $0 / 14$ & $0 / 18$ & $0 / 0$ & $1 / 0$ & 33 \\
\hline Myoplatypus flavicornis (Fabricius) & $\begin{array}{l}\text { Lower bole }\left(13.9^{* *}\right) \text {; } \\
\text { pine }\left(10.4^{*}\right)\end{array}$ & $0 / 0$ & $167 / 1$ & $0 / 0$ & $0 / 0$ & $65 / 0$ & $0 / 0$ & 233 \\
\hline Oxoplatypus quadridentatus Olivier & Oak (53.6”* $)$ & $761 / 966$ & $0 / 0$ & $38 / 1$ & $171 / 1896$ & $0 / 0$ & $0 / 0$ & 3833 \\
\hline Pityophthorus sp. 1 & $\begin{array}{l}\text { Sweetgum }\left(10.4^{*}\right) \text {; } \\
\text { crown }\left(10.9^{*}\right)\end{array}$ & $0 / 0$ & $0 / 0$ & $36 / 0$ & $0 / 0$ & $0 / 0$ & $3 / 24$ & 63 \\
\hline Pityophthorus sp. 2 & & $0 / 0$ & $0 / 4$ & $0 / 0$ & $0 / 0$ & $0 / 1$ & $0 / 0$ & 5 \\
\hline Pityophthorus sp. 3 & & $0 / 0$ & $0 / 0$ & $0 / 0$ & $0 / 0$ & $0 / 0$ & $11 / 0$ & 11 \\
\hline Pseudopentarthrum sp. & & $0 / 0$ & $0 / 0$ & $0 / 1$ & $0 / 0$ & $0 / 0$ & $0 / 0$ & 1 \\
\hline Pseudopityophthorus pruinosus (Eichhoff) & & $0 / 0$ & $0 / 0$ & $0 / 0$ & $1 / 5$ & $0 / 0$ & $0 / 0$ & 6 \\
\hline Rhyncolus sp. & Pine $\left(29.2^{* * *}\right)$; snag $\left(15^{* *}\right)$ & $0 / 0$ & $7 / 55$ & $0 / 0$ & $0 / 0$ & $1 / 355$ & $0 / 0$ & 418 \\
\hline Scolytus multistriatus (Marsham) & & $0 / 0$ & $0 / 0$ & $0 / 0$ & $0 / 1$ & $0 / 0$ & $0 / 0$ & 1 \\
\hline Stenoscelis andersoni Buchanan & $\begin{array}{l}\text { Bottomland }\left(13.9^{* *}\right) \text {; } \\
\text { snag }\left(13.9^{* *}\right)\end{array}$ & $0 / 1$ & $0 / 24$ & $0 / 11$ & $0 / 0$ & $0 / 0$ & $0 / 0$ & 36 \\
\hline Tomolips quercicola (Boheman) & & $0 / 2$ & $0 / 2$ & $0 / 3$ & $0 / 3$ & $0 / 0$ & $0 / 0$ & 10 \\
\hline Xyleborinus gracilis (Eichhoff) & & $0 / 0$ & $0 / 0$ & $0 / 0$ & $0 / 25$ & $0 / 0$ & $0 / 0$ & 25 \\
\hline Xyleborinus saxeseni (Ratzeburg) & Sweetgum $\left(22.8^{* * *}\right)$ & $0 / 0$ & $0 / 0$ & $441 / 36$ & $48 / 1$ & $0 / 0$ & $25 / 15$ & 566 \\
\hline Xyleborus affinis Eichhoff & $\begin{array}{l}\text { Lower bole }\left(18.4^{*}\right) ; \\
\text { sweetgum }\left(36.1^{* * *}\right)\end{array}$ & $1 / 4$ & $0 / 0$ & $473 / 998$ & $8 / 71$ & $1 / 0$ & $42 / 612$ & 2210 \\
\hline Xyleborus californicus Wood & & $0 / 1$ & $0 / 0$ & $0 / 0$ & $0 / 0$ & $0 / 0$ & $0 / 0$ & 1 \\
\hline Xyleborus ferrugineus (Fabricius) & $\begin{array}{l}\text { Lower bole }\left(24.7^{* *}\right) \text {; } \\
\text { pine }\left(28.2^{* * *}\right) ; \log \left(26.3^{* * *}\right)\end{array}$ & $20 / 0$ & $565 / 37$ & $154 / 14$ & $0 / 0$ & $182 / 0$ & $11 / 0$ & 983 \\
\hline Xyleborus pubescens Zimmermann & $\begin{array}{l}\text { Pine }\left(18.7^{* * *}\right) \\
\log \left(12.5^{* *}\right)\end{array}$ & $0 / 0$ & $13 / 0$ & $0 / 0$ & $0 / 0$ & $30 / 0$ & $0 / 0$ & 43 \\
\hline sp. 29 & & $0 / 0$ & $0 / 0$ & $0 / 0$ & $0 / 0$ & $0 / 0$ & $1 / 0$ & 1 \\
\hline
\end{tabular}


Appendix B (Continued)

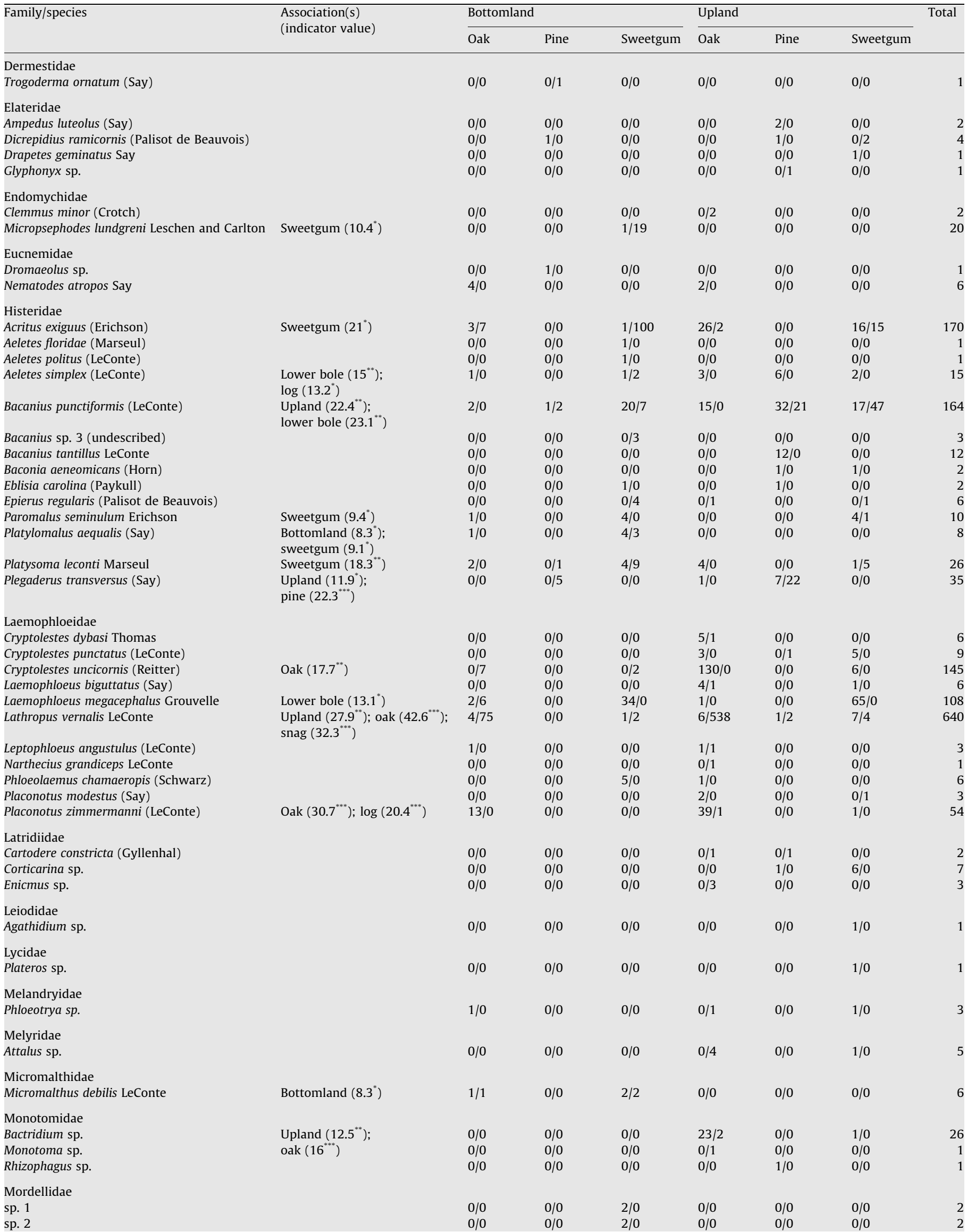


Appendix B (Continued)

\begin{tabular}{|c|c|c|c|c|c|c|c|c|}
\hline \multirow[t]{2}{*}{ Family/species } & \multirow{2}{*}{$\begin{array}{l}\text { Association(s) } \\
\text { (indicator value) }\end{array}$} & \multicolumn{3}{|c|}{ Bottomland } & \multicolumn{3}{|c|}{ Upland } & \multirow[t]{2}{*}{ Total } \\
\hline & & Oak & Pine & Sweetgum & Oak & Pine & Sweetgum & \\
\hline \multicolumn{9}{|l|}{ Mycetophagidae } \\
\hline Litargus sexpunctatus (Say) & Upland $\left(9.7^{*}\right)$; oak $\left(14.6^{* *}\right)$ & $0 / 0$ & $0 / 0$ & $0 / 0$ & $5 / 10$ & $0 / 0$ & $0 / 0$ & 15 \\
\hline Litargus sp. 2 & & $0 / 0$ & $0 / 0$ & $0 / 0$ & $1 / 0$ & $0 / 0$ & $0 / 0$ & 1 \\
\hline Mycetophagus pini Ziegler & & $0 / 0$ & $2 / 0$ & $0 / 0$ & $0 / 0$ & $1 / 0$ & $0 / 0$ & 3 \\
\hline Thrimolus minutus Casey & & $0 / 0$ & $0 / 0$ & $0 / 1$ & $0 / 0$ & $1 / 0$ & $0 / 0$ & 2 \\
\hline \multicolumn{9}{|l|}{ Nitidulidae } \\
\hline Carpophilus sp. 1 & & $0 / 0$ & $0 / 0$ & $0 / 0$ & $0 / 0$ & $1 / 0$ & $0 / 0$ & 1 \\
\hline Carpophilus sp. 2 & & $1 / 1$ & $0 / 0$ & $0 / 0$ & $0 / 2$ & $0 / 0$ & $0 / 0$ & 4 \\
\hline Epuraea luteolus (Erichson) & & $0 / 0$ & $0 / 0$ & $0 / 0$ & $1 / 1$ & $0 / 0$ & $1 / 0$ & 3 \\
\hline Prometopia sexmaculata (Say) & Upland $\left(21.2^{* * *}\right)$; oak & $4 / 0$ & $0 / 0$ & $2 / 0$ & $32 / 8$ & $4 / 1$ & $7 / 2$ & 60 \\
\hline Passandridae & & & & & & & & \\
\hline Catogenus rufus (Fabricius) & & $0 / 0$ & $0 / 0$ & $0 / 0$ & $0 / 0$ & $0 / 1$ & $0 / 0$ & 1 \\
\hline \multicolumn{9}{|l|}{ Phalacridae } \\
\hline sp. 1 & & $0 / 43$ & $0 / 0$ & $0 / 0$ & $0 / 0$ & $0 / 0$ & $0 / 0$ & 43 \\
\hline sp. 2 & & $0 / 0$ & $0 / 0$ & $0 / 0$ & $0 / 0$ & $0 / 0$ & $1 / 0$ & 1 \\
\hline \multicolumn{9}{|l|}{ Ptiliidae } \\
\hline spp. & Pine $\left(28.1^{* * *}\right)$ & $1 / 0$ & $32 / 222$ & $3 / 0$ & $0 / 0$ & $14 / 4$ & $1 / 5$ & 282 \\
\hline \multicolumn{9}{|l|}{ Pyrochroidae } \\
\hline Dendroides canadensis LeConte & & $0 / 0$ & $0 / 0$ & $0 / 0$ & $0 / 0$ & $0 / 0$ & $3 / 0$ & 3 \\
\hline \multicolumn{9}{|l|}{ Rhysodidae } \\
\hline Omoglymmius americanus (Laporte) & & $0 / 0$ & $0 / 0$ & $1 / 0$ & $0 / 0$ & $0 / 0$ & $0 / 0$ & 1 \\
\hline Scirtidae & & & & & & & & \\
\hline Cyphon sp. & & $0 / 0$ & $0 / 0$ & $1 / 1$ & $0 / 0$ & $0 / 0$ & $0 / 0$ & 2 \\
\hline Scraptiidae & & & & & & & & \\
\hline Canifa sp. & & $0 / 0$ & $0 / 0$ & $0 / 0$ & $0 / 0$ & $0 / 5$ & $0 / 0$ & 5 \\
\hline Scydmaenidae & & & & & & & & \\
\hline sp. 1 & & $0 / 0$ & $0 / 0$ & $0 / 0$ & $0 / 0$ & $1 / 0$ & $0 / 0$ & 1 \\
\hline sp. 2 & & $0 / 0$ & $0 / 0$ & $0 / 0$ & $0 / 0$ & $0 / 1$ & $0 / 0$ & 1 \\
\hline Silvanidae & & & & & & & & \\
\hline Ahasversus advena (Waltl) & & $3 / 1$ & $2 / 0$ & $0 / 2$ & $1 / 15$ & $0 / 1$ & $0 / 1$ & 26 \\
\hline Cathartosilvanus imbellis (LeConte) & & $0 / 0$ & $1 / 0$ & $0 / 5$ & $14 / 3$ & $0 / 0$ & $5 / 0$ & 28 \\
\hline Silvanus muticus Sharp & Upland $\left(9.9^{*}\right)$ & $0 / 0$ & $0 / 0$ & $1 / 0$ & $2 / 0$ & $2 / 0$ & $1 / 3$ & 9 \\
\hline Silvanus planatus Germar & & $0 / 0$ & $0 / 0$ & $0 / 0$ & $6 / 0$ & $0 / 0$ & $2 / 0$ & 8 \\
\hline Sphindidae & & & & & & & & \\
\hline Sphindus sp. & & $0 / 0$ & $1 / 0$ & $0 / 0$ & $0 / 0$ & $1 / 0$ & $4 / 0$ & 6 \\
\hline Staphylinidae & & & & & & & & \\
\hline Anacyptus testaceus (LeConte) & $\begin{array}{l}\text { Lower bole }\left(9.4^{*}\right) \text {; } \\
\text { pine }\left(10.4^{* *}\right)\end{array}$ & $0 / 0$ & $1 / 1$ & $0 / 0$ & $0 / 0$ & $36 / 0$ & $0 / 0$ & 38 \\
\hline Clavilispinus sp. & Lower bole $\left(41.3^{* * *}\right)$ & $38 / 99$ & $124 / 10$ & $28 / 153$ & $14 / 40$ & $90 / 0$ & $27 / 79$ & 702 \\
\hline Hesperus sp. & & $0 / 0$ & $0 / 0$ & $0 / 2$ & $0 / 0$ & $0 / 0$ & $0 / 0$ & 2 \\
\hline Homaeotarsus sp. & & $0 / 0$ & $0 / 0$ & $1 / 0$ & $0 / 0$ & $0 / 0$ & $0 / 0$ & 1 \\
\hline Myrmecocephalus sp. & Lower bole $\left(11.1^{*}\right)$ & $0 / 0$ & $3 / 1$ & $0 / 0$ & $0 / 6$ & $0 / 0$ & $0 / 1$ & 11 \\
\hline Myrmecosaurus ferrugineus Bruch & & $0 / 0$ & $0 / 0$ & $0 / 0$ & $0 / 0$ & $1 / 0$ & $0 / 0$ & 1 \\
\hline Scaphisoma sp. & & $0 / 0$ & $0 / 0$ & $0 / 0$ & $0 / 0$ & $0 / 0$ & $2 / 0$ & 2 \\
\hline Sunius sp. & & $0 / 0$ & $0 / 0$ & $0 / 0$ & $0 / 0$ & $0 / 0$ & $1 / 0$ & 1 \\
\hline Thoracophorus costalis (Erichson) & $\log \left(35.8^{* * *}\right)$ & $5 / 0$ & $4 / 0$ & $72 / 0$ & $28 / 0$ & $34 / 1$ & $83 / 10$ & 237 \\
\hline Toxidium sp. & & $0 / 0$ & $0 / 0$ & $0 / 1$ & $0 / 0$ & $0 / 0$ & $0 / 0$ & 1 \\
\hline sp11 & & $0 / 0$ & $1 / 0$ & $0 / 0$ & $1 / 0$ & $0 / 0$ & $0 / 0$ & 2 \\
\hline sp12 & & $0 / 0$ & $0 / 0$ & $0 / 3$ & $3 / 0$ & $0 / 0$ & $0 / 0$ & 6 \\
\hline sp13 & & $0 / 0$ & $0 / 0$ & $0 / 0$ & $1 / 0$ & $0 / 0$ & $1 / 0$ & 2 \\
\hline sp14 & & $0 / 0$ & $0 / 0$ & $0 / 0$ & $0 / 0$ & $0 / 0$ & $0 / 1$ & 1 \\
\hline sp15 & & $5 / 0$ & $0 / 0$ & $0 / 0$ & $0 / 0$ & $0 / 0$ & $0 / 0$ & 5 \\
\hline sp16 & Bottomland $\left(8.3^{*}\right)$ & $0 / 1$ & $0 / 3$ & $7 / 3$ & $0 / 0$ & $0 / 0$ & $0 / 0$ & 14 \\
\hline sp17 & & $0 / 0$ & $0 / 2$ & $0 / 0$ & $0 / 0$ & $0 / 0$ & $0 / 0$ & 2 \\
\hline sp18 & & $0 / 0$ & $0 / 1$ & $0 / 0$ & $0 / 0$ & $0 / 0$ & $0 / 0$ & 1 \\
\hline sp19 & & $0 / 0$ & $0 / 2$ & $0 / 0$ & $0 / 0$ & $0 / 0$ & $0 / 0$ & 2 \\
\hline sp20 & & $0 / 0$ & $1 / 6$ & $0 / 0$ & $0 / 0$ & $0 / 0$ & $0 / 0$ & 7 \\
\hline $\mathrm{sp} 21$ & & $0 / 0$ & $0 / 1$ & $0 / 0$ & $0 / 0$ & $0 / 0$ & $0 / 0$ & 1 \\
\hline sp22 & & $0 / 0$ & $0 / 1$ & $0 / 0$ & $0 / 0$ & $0 / 0$ & $0 / 0$ & 1 \\
\hline $\mathrm{sp} 23$ & & $0 / 0$ & $1 / 0$ & $0 / 0$ & $0 / 0$ & $0 / 0$ & $0 / 0$ & 1 \\
\hline $\mathrm{sp} 24$ & Pine $\left(18.7^{* * *}\right) ; \log \left(9.1^{*}\right)$ & $0 / 0$ & $3 / 2$ & $0 / 0$ & $0 / 0$ & $25 / 0$ & $0 / 0$ & 30 \\
\hline $\mathrm{sp} 25$ & & $0 / 0$ & $0 / 1$ & $0 / 0$ & $0 / 0$ & $0 / 0$ & $0 / 0$ & 1 \\
\hline sp26 & & $0 / 0$ & $0 / 1$ & $0 / 0$ & $0 / 0$ & $0 / 0$ & $0 / 0$ & 1 \\
\hline $\mathrm{sp} 27$ & Pine $\left(8.3^{*}\right)$ & $0 / 0$ & $1 / 0$ & $0 / 0$ & $0 / 0$ & $3 / 0$ & $0 / 0$ & 4 \\
\hline $\mathrm{sp} 28$ & Sweetgum $\left(15.5^{*}\right)$ & $0 / 0$ & $0 / 0$ & $83 / 36$ & $0 / 0$ & $4 / 6$ & $9 / 0$ & 138 \\
\hline sp29 & & $0 / 0$ & $0 / 0$ & $1 / 0$ & $0 / 0$ & $0 / 0$ & $0 / 0$ & 1 \\
\hline sp30 & & $0 / 0$ & $0 / 0$ & $1 / 0$ & $1 / 0$ & $0 / 0$ & $0 / 0$ & 2 \\
\hline
\end{tabular}


Appendix B (Continued)

\begin{tabular}{|c|c|c|c|c|c|c|c|c|}
\hline \multirow[t]{2}{*}{ Family/species } & \multirow{2}{*}{$\begin{array}{l}\text { Association(s) } \\
\text { (indicator value) }\end{array}$} & \multicolumn{3}{|l|}{ Bottomland } & \multicolumn{3}{|l|}{ Upland } & \multirow[t]{2}{*}{ Total } \\
\hline & & Oak & Pine & Sweetgum & Oak & Pine & Sweetgum & \\
\hline sp31 & & $0 / 0$ & $0 / 0$ & $14 / 0$ & $0 / 0$ & $0 / 0$ & $0 / 0$ & 14 \\
\hline sp32 & & $0 / 0$ & $0 / 0$ & $0 / 1$ & $0 / 0$ & $0 / 0$ & $1 / 0$ & 2 \\
\hline sp33 & & $0 / 0$ & $0 / 0$ & $0 / 0$ & $0 / 0$ & $2 / 0$ & $0 / 0$ & 2 \\
\hline sp34 & & $0 / 0$ & $0 / 0$ & $0 / 0$ & $0 / 0$ & $0 / 0$ & $0 / 4$ & 4 \\
\hline sp35 & & $0 / 0$ & $0 / 0$ & $0 / 0$ & $0 / 0$ & $0 / 0$ & $1 / 0$ & 1 \\
\hline sp36 & & $0 / 0$ & $0 / 0$ & $0 / 0$ & $0 / 0$ & $1 / 0$ & $0 / 0$ & 1 \\
\hline sp37 & & $0 / 0$ & $0 / 0$ & $0 / 0$ & $0 / 0$ & $0 / 1$ & $0 / 0$ & 1 \\
\hline sp38 & & $0 / 0$ & $0 / 0$ & $0 / 0$ & $0 / 0$ & $2 / 0$ & $0 / 0$ & 2 \\
\hline sp39 & & $0 / 0$ & $0 / 0$ & $0 / 0$ & $0 / 0$ & $1 / 0$ & $0 / 0$ & 1 \\
\hline sp40 & & $0 / 0$ & $0 / 0$ & $0 / 0$ & $0 / 0$ & $2 / 0$ & $0 / 0$ & 2 \\
\hline sp41 & & $0 / 0$ & $2 / 1$ & $1 / 0$ & $0 / 0$ & $0 / 1$ & $0 / 0$ & 5 \\
\hline sp42 & & $0 / 0$ & $0 / 0$ & $0 / 0$ & $1 / 0$ & $0 / 0$ & $0 / 0$ & 1 \\
\hline sp43 & & $0 / 0$ & $0 / 0$ & $0 / 0$ & $0 / 0$ & $0 / 2$ & $0 / 0$ & 2 \\
\hline sp44 & & $0 / 0$ & $0 / 0$ & $1 / 1$ & $0 / 0$ & $0 / 0$ & $0 / 0$ & 2 \\
\hline sp45 & & $0 / 0$ & $0 / 0$ & $0 / 0$ & $0 / 0$ & $0 / 0$ & $1 / 0$ & 1 \\
\hline sp46 & & $0 / 0$ & $0 / 0$ & $0 / 1$ & $0 / 0$ & $0 / 0$ & $0 / 0$ & 1 \\
\hline sp47 & & $0 / 0$ & $0 / 0$ & $0 / 0$ & $0 / 0$ & $1 / 0$ & $0 / 0$ & 1 \\
\hline sp48 & & $0 / 0$ & $0 / 1$ & $0 / 0$ & $0 / 0$ & $0 / 0$ & $0 / 0$ & 1 \\
\hline sp49 & & $0 / 0$ & $0 / 0$ & $0 / 1$ & $0 / 0$ & $0 / 0$ & $0 / 0$ & 1 \\
\hline \multicolumn{9}{|l|}{ Synchroidae } \\
\hline Synchroa punctata Newman & & $1 / 0$ & $0 / 0$ & $0 / 0$ & $0 / 0$ & $0 / 0$ & $0 / 0$ & 1 \\
\hline \multicolumn{9}{|l|}{ Tenebrionidae } \\
\hline Adelina pallida (Say) & & $0 / 0$ & $0 / 0$ & $0 / 0$ & $0 / 0$ & $0 / 0$ & $0 / 3$ & 3 \\
\hline Alobates pennsylvanica (DeGeer) & Lower bole $\left(9.9^{*}\right)$ & $0 / 0$ & $0 / 0$ & $3 / 1$ & $0 / 1$ & $0 / 1$ & $0 / 1$ & 7 \\
\hline Corticeus thoracicus (Melsheimer) & Lower bole $\left(24.2^{* * *}\right)$ & $3 / 0$ & $55 / 6$ & $27 / 113$ & $0 / 4$ & $76 / 0$ & $0 / 2$ & 286 \\
\hline Gnathocerus maxillosus (Fabricius) & & $0 / 0$ & $0 / 0$ & $0 / 0$ & $0 / 1$ & $0 / 0$ & $0 / 0$ & 1 \\
\hline Hymenorus sp. & & $0 / 0$ & $0 / 0$ & $15 / 0$ & $0 / 0$ & $0 / 0$ & $0 / 0$ & 15 \\
\hline Liodema laeve (Haldeman) & $\begin{array}{l}\text { Lower bole }\left(16.7^{* * *}\right) \text {; } \\
\text { snag }\left(8.3^{*}\right)\end{array}$ & $0 / 1$ & $0 / 0$ & $0 / 16$ & $0 / 1$ & $0 / 0$ & $0 / 1$ & 19 \\
\hline Lobopoda erythrocnemis Germar & & $0 / 0$ & $0 / 0$ & $0 / 0$ & $0 / 0$ & $1 / 0$ & $0 / 0$ & 1 \\
\hline Platydema excavatum (Say) & & $0 / 0$ & $0 / 0$ & $0 / 0$ & $1 / 0$ & $0 / 0$ & $0 / 0$ & 1 \\
\hline Platydema flavipes (Fabricius) & Pine $\left(13.6^{*}\right) ; \log \left(14.4^{* *}\right)$ & $0 / 0$ & $13 / 0$ & $2 / 0$ & $0 / 0$ & $14 / 0$ & $2 / 2$ & 33 \\
\hline Platydema picilabrum Melsheimer & & $0 / 1$ & $0 / 0$ & $0 / 0$ & $0 / 0$ & $0 / 0$ & $0 / 0$ & 1 \\
\hline Platydema ruficorne (Stürm) & $\begin{array}{l}\text { Lower bole }\left(13.6^{*}\right) ; \\
\text { pine }\left(11.7^{*}\right) ; \log \left(11^{*}\right)\end{array}$ & $4 / 0$ & $142 / 0$ & $0 / 0$ & $0 / 0$ & $59 / 2$ & $10 / 0$ & 217 \\
\hline Platydema subcostatum Laporte and Brulle & & $1 / 0$ & $0 / 0$ & $0 / 0$ & $0 / 0$ & $0 / 0$ & $1 / 0$ & 2 \\
\hline Poecilocrypticus formicophilus Gebien & & $0 / 0$ & $0 / 0$ & $0 / 0$ & $0 / 0$ & $0 / 1$ & $0 / 0$ & 1 \\
\hline \multicolumn{9}{|l|}{ Tetratomidae } \\
\hline Eustrophus tomentosus Say & & $0 / 0$ & $0 / 0$ & $1 / 0$ & $0 / 0$ & $0 / 0$ & $0 / 0$ & 1 \\
\hline \multicolumn{9}{|l|}{ Throscidae } \\
\hline sp. & & $0 / 0$ & $1 / 0$ & $0 / 0$ & $0 / 0$ & $0 / 0$ & $0 / 0$ & 1 \\
\hline \multicolumn{9}{|l|}{ Trogossitidae } \\
\hline Airora cylindrica (Serville) & Pine $\left(19.9^{* * *}\right)$; snag $\left(16.9^{* *}\right)$ & $0 / 0$ & $1 / 13$ & $0 / 1$ & $0 / 2$ & $1 / 11$ & $0 / 1$ & 30 \\
\hline Corticotomus cylindricus (LeConte) & & $0 / 0$ & $0 / 0$ & $0 / 0$ & $0 / 0$ & $0 / 1$ & $0 / 0$ & 1 \\
\hline Lycoptis americana (Motschulsky) & & $0 / 0$ & $0 / 0$ & $0 / 0$ & $0 / 0$ & $0 / 1$ & $0 / 0$ & 1 \\
\hline Temnoscheila virescens (Fabricius) & Sweetgum $\left(41.2^{* * *}\right)$ & $5 / 3$ & $0 / 1$ & $16 / 19$ & $2 / 8$ & $1 / 2$ & $8 / 10$ & 75 \\
\hline Tenebroides bimaculatus (Melsheimer) & & $0 / 4$ & $0 / 0$ & $0 / 0$ & $0 / 0$ & $0 / 0$ & $0 / 0$ & 4 \\
\hline Tenebroides collaris (Sturm) & & $0 / 0$ & $1 / 1$ & $0 / 0$ & $0 / 0$ & $0 / 2$ & $0 / 0$ & 4 \\
\hline Tenebroides corticalis (Melsheimer) & $\begin{array}{l}\text { Lower bole }\left(18.6^{*}\right) \text {; } \\
\log \left(25.8^{* *}\right)\end{array}$ & $5 / 2$ & $18 / 0$ & $7 / 3$ & $10 / 0$ & $2 / 0$ & $9 / 10$ & 66 \\
\hline Tenebroides laticollis (Horn) & Oak $\left(16.3^{* *}\right)$ & $1 / 1$ & $0 / 0$ & $0 / 0$ & $1 / 38$ & $0 / 0$ & $1 / 0$ & 42 \\
\hline Tenebroides marginatus (Palisot de Beauvois) & $\begin{array}{l}\text { Upland }\left(9^{*}\right) \text {; lower bole } \\
\left(10.9^{*}\right) \text {; pine }\left(8.3^{*}\right)\end{array}$ & $0 / 0$ & $0 / 1$ & $0 / 0$ & $6 / 0$ & $2 / 5$ & $0 / 0$ & 14 \\
\hline Tenebroides nanus (Melsheimer) & $\begin{array}{l}\text { bottomland }\left(12.4^{*}\right) \text { oak } \\
\left(11.8^{*}\right) \text { snag }\left(16.7^{* *}\right)\end{array}$ & $0 / 30$ & $0 / 0$ & $0 / 3$ & $0 / 0$ & $0 / 0$ & $0 / 4$ & 37 \\
\hline Tenebroides semicylindricus (Horn) & Snag $\left(14.1^{* *}\right)$; crown $\left(12^{*}\right)$ & $0 / 2$ & $0 / 4$ & $0 / 0$ & $1 / 2$ & $0 / 0$ & $0 / 4$ & 13 \\
\hline Thymalus marginicollis Chevrolat & & $0 / 0$ & $0 / 0$ & $0 / 0$ & $0 / 0$ & $0 / 0$ & $1 / 0$ & 1 \\
\hline \multicolumn{9}{|l|}{ Zopheridae } \\
\hline Hyporhagus punctulatus Thomson & & $0 / 0$ & $0 / 0$ & $0 / 0$ & $1 / 0$ & $0 / 0$ & $3 / 0$ & 4 \\
\hline Pycnomerus haematodes (Fabricius) & $\begin{array}{l}\text { Upland }\left(13.2^{* *}\right) \\
\text { pine }\left(20.6^{* * *}\right)\end{array}$ & $0 / 0$ & $0 / 4$ & $0 / 0$ & $0 / 0$ & $11 / 64$ & $1 / 0$ & 80 \\
\hline Pycnomerus reflexus (Say) & $\begin{array}{l}\text { Bottomland }\left(19.4^{* * *}\right) \text {; } \\
\text { lower bole }\left(12.3^{*}\right) \text {; } \\
\log \left(14.5^{* *}\right)\end{array}$ & $28 / 0$ & $5 / 0$ & $22 / 3$ & $0 / 0$ & $0 / 0$ & $0 / 0$ & 58 \\
\hline Pycnomerus sulcicollis LeConte & $\begin{array}{l}\text { Lower bole }\left(20.3^{* *}\right) \text {; } \\
\text { pine }\left(15.2^{*}\right) ; \log \left(22.2^{* * *}\right)\end{array}$ & $2 / 0$ & $6 / 0$ & $3 / 0$ & $3 / 0$ & $33 / 0$ & $1 / 0$ & 48 \\
\hline Total number of individuals & & $4262 / 2608$ & $1552 / 1837$ & $2799 / 2918$ & $3633 / 4452$ & $1683 / 2297$ & $2470 / 2946$ & 33457 \\
\hline Number of species, total & & $58 / 45,76$ & $56 / 51,83$ & $72 / 66,100$ & $72 / 65,97$ & $71 / 46,92$ & $85 / 53,105$ & 250 \\
\hline
\end{tabular}




\section{References}

Arnett, Jr., R.H., Thomas, M.C. (Eds.), 2001. American Beetles: Archostemata, Myxophaga, Adephaga, Polyphaga: Staphyliniformia. CRC Press, Boca Raton, Florida.

Arnett, Jr., R.H., Thomas, M.C. (Eds.), 2002. American Beetles: Polyphaga: Scarabaeiodea through Curculionoidea. CRC Press, Boca Raton, Florida.

Bouget, C., Duelli, P., 2004. The effects of windthrow on forest insect communities: a literature review. Biol. Conserv. 118, 281-299.

Boulanger, Y., Sirois, L., 2007. Postfire succession of saproxylic arthropods, with emphasis on Coleoptera, in the north boreal forest of Quebec. Env. Ent. 36, 128141.

Colwell, R.K., 2006. EstimateS: Statistical Estimation of Species Richness and Shared Species from Samples. Version 8. Available at: http://www.purl.oclc.org/estimates.

Colwell, R.K., Coddington, J.A., 1994. Estimating terrestrial biodiversity through extrapolation. Philos. Trans. R. Soc. Lond. B 345, 101-118.

Conner, R.N., Saenz, D., 2005. The longevity of large pine snags in eastern Texas. Wildl. Soc. Bull. 33, 700-705.

Dufrêne, M., Legendre, P., 1997. Species assemblages and indicator species: the need for a flexible asymmetrical approach. Ecol. Monograph 67, 345-366.

Evans, W.G., 1966. Perception of infrared radiation from forest fires by Melanophila acuminate De Geer (Buprestidae: Coleoptera). Ecology 47, 1061-1065.

Fonte, S.J., Schowalter, T.D., 2004. Decomposition in forest canopies. In: Lowman, M.D., Rinker, H.B. (Eds.), Forest Canopies. Elsevier Academic Press, Burlington, Massachusetts, pp. 413-422.

Franc, N., 2007. Standing or downed dead trees-does it matter for saproxylic beetles in temperate oak-rich forest? Can. J. For. Res. 37, 2494-2507.

Gibb, H., Pettersson, R.B., Hjältén, J., Hilszczański, J., Ball, J.P., Johansson, T., Atlegrim, O., Danell, K., 2006. Conservation-oriented forestry and early successional saproxylic beetles: responses of functional groups to manipulated dead wood substrates. Biol. Conserv. 129, 437-450.

Grove, S.J., 2006. A research agenda for insects and dead wood. In: Grove, S.J., Hanula, J.L. (Eds.), Insect Biodiversity and Dead Wood: Proceedings of a Symposium for the 22nd International Congress of Entomology. USDA For. Serv., Gen. Tech. Rep. SRS-93, pp. 98-108.

Harding, R., 2007. Georgia forests: epicenter of the bioenergy corridor. Georgia Forestry Today (November/December), 12-15.

Hedgren, P.O., Schroeder, L.M., 2004. Reproductive success of the spruce bark beetle Ips typographus (L.) and occurrence of associated species: a comparison between standing beetle-killed trees and cut trees. For. Ecol. Manage. 203, 241-250.

Hjältén, J., Johansson, T., Alinvi, O., Danell, K., Ball, J.P., Pettersson, R., Gibb, H. Hilszczański, J., 2007. The importance of substrate type, shading and scorching for the attractiveness of dead wood to saproxylic beetles. Basic Appl. Ecol. 8, 364-376.

Jomura, M., Kominami, Y., Dannoura, M., Kanazawa, Y., 2008. Spatial variation in respiration from coarse woody debris in a temperate secondary broad-leaved forest in Japan. For. Ecol. Manage. 255, 149-155.
Jonsell, M., Hansson, J., 2007. Comparison of methods for sampling saproxylic beetles in fine wood. Entomol. Fenn. 18, 232-241.

Jonsell, M., Weslien, J., 2003. Felled or standing retained wood-it makes a difference for saproxylic beetles. For. Ecol. Manage. 175, 425-435.

Jonsell, M., Weslien, J., Ehnström, B., 1998. Substrate requirements of red-listed saproxylic invertebrates in Sweden. Biodivers. Conserv. 7, 749-764.

Kappes, H., Topp, W., 2004. Emergence of Coleoptera from deadwood in a managed broadleaved forest in central Europe. Biodivers. Conserv. 13, 1905-1924.

Kilgo, J.C., Blake, J.I. (Eds.), 2005. Ecology and Management of a Forested Landscape: Fifty years on the Savannah River Site. Island Press, Washington, DC.

Larkin, P.A., Elbourn, C.A., 1964. Some observations on the fauna of dead wood in live oak trees. Oikos $15,79-92$.

Lindhe, A. Lindelöw, A. Asenblad, N., 2005. Saproxylic beetles in standing dead wood density in relation to substrate sun-exposure and diameter. Biodivers. Conserv. 14, 3033-3053.

Lohr, S.M., Gauthreaux, S.A., Kilgo, J.C., 2002. Importance of coarse woody debris to avian communities in Loblolly pine forests. Conserv. Biol. 16, 767-777.

McCune B., Grace, J.B., 2002. Analysis of Ecological Communities. MjM Software Design. Gleneden Beach, Oregon.

McCune, B., Mefford, M.J., 2006. PC-ORD. Multivariate Analysis of Ecological Data. Version 5. MJM Software. Gleneden Beach, Oregon.

McGeoch, M.A., Schroeder, M., Ekbom, B., Larsson, S., 2007. Saproxylic beetle diversity in a managed boreal forest: importance of stand characters and forestry conservation measures. Diversity Distrib. 13, 418-429.

Moorman, C.E., Russell, K.R., Sabin, G.R., Guynn Jr., D.C., 1999. Snag dynamics and cavity occurrence in the South Carolina piedmont. For. Ecol. Manage. 118, 37-48.

Moretti, M., Obrist, M.K., Duelli, P., 2004. Arthropod biodiversity after forest fires: Winners and losers in the winter fire regime of the southern Alps. Ecography 27. 173-186.

Müller, J., Goßner, M., 2007. Single host trees in a closed forest canopy matrix: a highly fragmented landscape? J. Appl. Entomol. 131, 613-620.

Nordén, B., Götmark, F., Tönnberg, M., Ryberg, M., 2004. Dead wood in semi-natural temperate broadleaved woodland: contribution of coarse and fine dead wood, attached dead wood and stumps. For. Ecol. Manage. 194, 235-248.

Økland, B., 2002. Canopy cover favours sporocarp-visiting beetles in spruce forest. Norw. J. Entomol. 49, 29-39.

SAS Institute, 1990. SAS Guide for Personal Computers. SAS Institute, Cary, NC, USA

Schultz, R.P., 1997. Loblolly Pine: The Ecology and Culture of Loblolly Pine (Pinus taeda L.). Agricultural Handbook, vol. 713. USDA Forest Service, Washington, DC

Sverdrup-Thygeson, A., Ims, R.A., 2002. The effect of forest clearcutting in Norway on the community of saproxylic beetles on aspen. Biol. Conserv. 106, 347-357.

Warriner, M.D., Nebeker, T.E., Tucker, S.A, Schiefer, T.L., 2004. Comparison of saproxylic beetle (Coleoptera) assemblages in upland hardwood and bottomland hardwood forests. In: Spetich, M.A. (Ed.), Upland Oak Ecology Symposium History, Current Conditions, and Sustainability. USDA For. Serv., Gen. Tech. Rep. SRS-73, pp. 150-153.

Wear, D.N., 1996. Forest Management and Timber Production in the U.S. South. Southeastern Center for Forest Economics Research. SCFER Working Paper No. 82. Research Triangle Park, NC. 